British Journal of Chinese Studies, Vol. 11, July 2021

ISSN 2048-0601

(C) British Association for Chinese Studies

\title{
Becoming "British East Asian and Southeast Asian": Anti-racism, Chineseness, and Political Love in the Creative and Cultural Industries
}

Diana Yeh

City, University of London

\begin{abstract}
This article advances work on the "British Chinese" by reconfiguring the boundaries of the field and expanding it beyond the cultural and linguistic transformations of an "ethnic community." To do so, I examine recent political mobilisation of a pan-East and Southeast Asian identity in the creative and cultural industries and situate it within wider anti-racist organising in Britain. First, I examine the birthing of "British East and Southeast Asianness" as an emphatically political identity that contests racialised notions of "the Chinese" as a passive "model minority" and articulates a repositioning as agents of change. Second, I examine the crafting of a political community by members of two collectives in which this identity emerges as a contestation of the borders of "Chineseness" and its policing, while maintaining a Chinese hegemony. Third, I identify distinct political repertoires of anti-racism within this "community," a more radical and a more integrationist approach, which highlights the challenges of political mobilisation, and which are shaped by a continued abject status. Finally, I explore the role of political love and care as a means of mobilisation, through which a radical politics of affirmation and refusal is crafted. In doing so, I re-envision the political horizons of the so-called "British Chinese," while shedding light on the current complexities, transformations, and solidarities of communities within and beyond Chineseness.
\end{abstract}

Keywords: British Chinese, British East Asian, British Southeast Asian, political community, anti-racism, Chineseness, identity, model minority, political love, care

\section{Introduction}

The last few decades have seen a significant increase in the Chinese population in Britain and the formation of new communities. Yet it remains the case that the complexity of "Chineseness" in Britain has not been adequately captured in research. While earlier studies mainly focused on the Hong Kong Chinese, much recent work examines newer migrations from mainland China, leaving more established generations of Chinese relatively obscured, and contributing to the construction of the diversity of this so-called "community" as a present phenomenon rather than a longstanding fact. Part of the work of documenting and conceptualising the remapping of the Chinese in Britain must therefore involve reflecting the complexity of more established as well as newer communities and examining how these are transforming. ${ }^{1}$

This article attempts to do this by focusing on the political communities of so-called "British Chinese" in the creative and cultural industries (CCIs) which transcend "Chineseness."

\footnotetext{
${ }^{1}$ This paper was first presented at the "Remapping the Cultural and Linguistic Landscape of the Chinese in Britain” conference, University of Westminster, February 15, 2020.
} 
Specifically, it examines the mobilisation of the category "British East and Southeast Asian" as a political identity among a group of cultural leaders now associated with the non-profit organisation BEATS (British East Asians ${ }^{2}$ in the Theatre and on Screen), some of whom were also former members of the collective BEAA (British East Asian Artists). Through different forms of advocacy in the screen and stage industries, BEAA and BEATS have brought together "Chinese" cultural workers of a range of backgrounds (such as British, Singaporean, Malaysian, etc.) with others of different "Asian" ethnicities (such as Vietnamese, Korean, Indonesian, Japanese, etc.).

By examining the emergence of new "British East and Southeast Asian" identities, this article foregrounds the formation of political (as opposed to cultural and linguistic) communities among the "British Chinese." In doing so, it highlights the complexity of the category "Chinese" that existed prior to the new migrations, and the negotiation of identities, borders, and belongings of "the British Chinese," both within and beyond "Chineseness." First, I examine the weaponisation of "British East and Southeast Asianness" by participants as an emphatically political identity, which contests racialised notions of "the Chinese" as a passive and submissive "model minority" and repositions members as political actors and agents of change. Second, I examine the crafting of a political community, in which a pan-Asian identity emerges as a direct contestation of the borders of "Chineseness" and its policing, while nonetheless maintaining a Chinese hegemony. ${ }^{3}$ Third, I identify distinct political repertoires of anti-racism within this stage and screen "community," a more radical approach and a more integrationist approach, ${ }^{4}$ which are reflective of wider East and Southeast Asian groups. This highlights the challenges of political mobilisation and ideological contestations within the community, which are shaped by the continued abject status of East and Southeast Asians in British society. In the final section, I interrogate past and present theorisations on the role of political love and care as a means of mobilisation and countering this abject status. I argue that participants can be seen to be crafting both a radical politics of affirmation and refusal through their deployment of love and care. This article advances work on the "British Chinese" by reconfiguring the boundaries of the field beyond a narrowly culturalist focus on transformations of an "ethnic community" to include important politicised dynamics of pan-Asian political solidarity and locates them within wider anti-racist organising among racially minoritised groups in Britain.

The move towards British East and Southeast Asian identity in the CCIs since the 2000s is part of the legacy of the fragmentation of a "Black" political identity in the 1980s and its appropriation in policy during the 1990s (Yeh, 2018). Yet the particular articulation of pan-Asian political mobilisation by BEAA/BEATS can also be situated in relation to broader anti-racist movements emerging from the global economic and political crisis of the ensuing decade, from the 2008 economic crash and politics of austerity to an increasingly hostile environment, securitisation, everyday bordering, and "mainstreaming of the far right" (Mondon and Winter, 2020). As Bassel and Emejulu (2017) point out, such developments have led to new forms of political organising and resistance, not least by minoritised women of colour.

This article contributes to a range of recent work that sheds light on these anti-racist mobilisations among Britain's Black and Asian communities and other racially minoritised

\footnotetext{
${ }^{2}$ As detailed below, the term "British East Asian" has been used in the stage and screen industries in a problematic way to include Southeast Asia.

${ }^{3}$ In this article, for brevity, I use the term "pan-Asian" unless otherwise specified, to refer to pan-"East and Southeast Asian" identity, as used in the field, while mindful of ongoing debates around "Asianness" and that some constructions of "pan-Asianness" in the East and Southeast Asian community also include South Asia.

${ }^{4}$ While these repertoires are analytically distinct, groups and individuals may occupy various positionings along this continuum at different times.
} 
groups, including those that focus on the work of women (Bassel and Emejulu, 2017) and on work specifically in the CCIs (Saha, 2013; Vrikki and Malik, 2019). In the context of the latter, austerity policies led to a 30 percent reduction to the central Arts Council budget in 2010 (Harvie, 2015), and there has been an entrenchment of what Littler (2018) has called "a postracial neoliberal meritocracy" across the sector. This has seen a growth of diversity discourses accompanied by rising racial inequalities and persistent representational violence. Orientalising tropes, for example, continue to appear across the media, such as in the "Blind Banker" episode of the BBC television series Sherlock (2010) and BBC Radio 4's Fu Manchu in Edinburgh (2010). In 2011, Art Council England's cuts led to Britain's only revenue-funded "British East Asian" theatre company - the controversially named Yellow Earth Theatre (therefore, recently renamed the New Earth Theatre) - losing its funding.

However, thus far there has been little examination of the role of Britain's Chinese communities in anti-racist work. As Bassel and Emejulu (2017) suggest, the construction of political space in Europe and specific dominant imagery of the activist as white and male disavows the political agency of racially minoritised groups - especially women. In the case of East and Southeast Asians, this is aggravated by the racialised construction of "the Chinese" (and sometimes by extension, other East and Southeast Asians, who are often mistaken or conflated as Chinese) as an apolitical model minority (Yeh, 2014, 2018), as has previously been the case with South Asians (Parmar, 1982; Huq, 1996). However, there has also been a lack of engagement among scholars working on British Chinese communities with questions of politics, activism, or anti-racism, mirroring the split, shaped by colonial legacies, between British sociological work on "race," focusing on African Caribbeans, and anthropological accounts of "ethnicity," focusing on Asians (Alexander, 2002).

Parker (2003) and Parker and Song's (2006, 2007, 2009) work provides an important exception. They examined changing identifications among young British Chinese via websites, exploring negotiations and contestations around constructions of British Chinese identity and its borders. Significantly, they also highlighted a nascent civil society by examining the political mobilisation of Chinese communities across generations in response to the deaths of the fiftyeight young would-be migrants in Dover in 2000, as well as against the scapegoating surrounding the outbreak of foot and mouth disease in 2001, in which the Chinese catering trade was identified as a possible source of the outbreak (Parker and Song, 2007). They also document protests against cultural institutions, when, for example, in 2002, the British Chinese Online website ran a campaign challenging the erasure of the opium trade from a British Library exhibition. Beyond a few exceptions such as these, the history of East and Southeast Asian anti-racist activism largely remains unwritten and this article contributes to the documentation of these uncharted stories. In doing so, it is significant in reinscribing East and Southeast Asians, and particularly women (most of BEATS' members identify as women) as political agents, as opposed to silent, passive subjects.

The context of BEATS' mobilisation of a pan-Asian identity - and its significance -takes place in the context of demographic change. East and Southeast Asians form one of the fastestgrowing ethnic groups in the UK (ONS, 2011), and represent the largest ethnic group among international students in the UK (HESA 2019/20. Amid the global rise of China, new claims of British Chinese identification by recent migrants, especially from mainland China, are altering meanings of British Chineseness and producing new hierarchies of visibility. In the CCIs, these hierarchies are constructed in relation to capital, as well as longstanding conceptions of authenticity, measured in proximity to "China," and thus risk rendering longstanding British Chinese populations invisible (Yeh, 2018). It is imperative that academic work is not complicit in this. Knowles and Burrows (2017: 90), for example, argue that "Chinese London is now primarily about new migrants instead of the settled UK-born," as China-born migrants in London form two-thirds of the ethnic Chinese population (according to the 2011 Census) and as Chinese capital reshapes the city. Yet acknowledging instead a multiplicity of "Chinese Londons," at times 
overlapping, enables a perspective that engages rather than erases the complexity of "the Chinese." The work of BEAA/BEATS may not be noteworthy in terms of capital or numbers of members, but in organising protests against key national cultural institutions, they are significant in crafting a new visible identity that is challenging the abject place of the Chinese and wider East and Southeast Asian communities in British society.

In the US, Asian American mobilisation has a recognised history, but in Britain there has been little comparative research on pan-Asian organising. Benton and Gomez (2008) have suggested that there has been little evidence of pan-ethnic formations among British Chinese youth. More recently, I have discussed the emergence of pan-ethnic racial identities among young Chinese in Britain through the formation of "British Chinese" or the problematically named "Oriental" nightlife parties scattered across urban Britain, which bring together youth of a range of ethnicities including Japanese, Korean, Singaporean, Filipino, Vietnamese, Burmese, and Taiwanese (Yeh, 2014a, 2014b). Barber (2015) notes similar pan-ethnic identifications among British Vietnamese youth. In these works, the formation of pan-Asian identifications has led to new social and cultural politics, which enable the re-imagining of ethnicised and racialised subjects. Yet, in line with South Asian Desi nights examined by Kim (2016), these new formations can conform to individualist, neoliberal models of identity - consumerist, aspirational, heteronormative, and inward-looking - rather than leading to any anti-racist mobilisation.

In this article, I focus on the perspectives of founder members of BEAA and BEATS, launched in 2012 and 2018, respectively. Composed of cultural workers in their thirties to fifties, the collectives demonstrate the significance of broader-based alliances among so-called "British Chinese" and their active engagements in direct forms of anti-racist mobilisation in tackling structural inequalities in the CCIs. Members are also active in other political networks focusing, for example, on migrants' rights, transracial adoption, environmentalism, LGBT/queer rights, and pro-democracy campaigning, which inform their politics and work within the CCIs. BEATS includes three key members (Lucy Sheen, Daniel York Loh, and Jennifer Lim) of the former BEAA, who are arguably among the central architects of a pan-Asian political project in the CCIs, having led a high-profile public protest against the Royal Shakespeare Company in 2012, under a self-consciously politicised British East (and Southeast) Asian identity (detailed below). Of these, Loh and Sheen also run the British East/Southeast Asian (BESEA) Actors and Artists Discussion Forum on Facebook, set up in 2015, which at the time of writing has 3,700 members. Through these channels, these leaders have had a significant impact on a wider community of East and Southeast Asians in the CCIs, especially a younger generation, as well as success in driving forward the position of the East and Southeast Asians in Britain more widely in terms of representational politics in the CCIs.

My analysis draws on a series of interviews and focus groups with some of the most active members of BEATS as well as insights from informal conversations as an observer and of participant in the group, as well as cultural events and performances. As a peripheral member of the group and an academic (as opposed to working on stage or in the screen industry), I see myself as a "partner in struggle," my stance rendering explicit the political stakes of my work (Kondo, 2014: 22). In documenting and analysing these new expressions of political subjectivity, I contribute to a repositioning of British East and Southeast Asians as political actors and agents of change. By refusing the "taken-for-grantedness" of community, I highlight the collective negotiations and labour involved in mobilising as a political community. Focusing particularly on pan-Asian mobilisation contributes to reconceptualising the field of British Chinese studies by highlighting its inseparability from work on wider community formations, and by introducing a dynamic of politicisation to the literature, which sheds light on the complexities, transformations and political solidarities of Britain's “Chinese” communities. 


\section{The Birth of a Political Identity}

In the little existing work on a pan-Asian identity in the UK, which also focuses on some members of BEAA but has emerged in theatre studies, "British East (and Southeast) Asian identity" has conceptualised as an artistic affiliation, giving rise to "creative" and "aesthetic" differences, but not one that is rooted in political activism and that articulates ideological contestation (Rogers, 2015; Thorpe, 2018). By contrast, I want to suggest BEAA/BEATS' mobilisation as expressing an explicitly political subjectivity, which contests racialised notions of the model minority in tackling structural inequalities in the CCIs and carves out a distinctive politics that at times separates members from the wider stage and screen community. As I discuss in this section, this subjectivity is shaped by wider racial politics in Britain as well as connected to transatlantic and global imaginings of "Asian” community, which are infused by a dynamics of love.

The formation of "British East and Southeast Asian" communities is in part a necessary response to a precarious position within wider anti-racist movements shaped by colonial legacies (Yeh, 2018). As Lucy Sheen, who has been acting since the mid-1980s, recalled:

When I was a student, there was South Africa, Palestine, marches against NF [National Front]. In the seventies, it didn't matter what colour you were. I embraced "Black" in sense of "non-white," but when that changed it became even more problematic. We couldn't call ourselves "Asian” so where do you align yourself? We had nowhere to align ourselves.

Under the new ethnicised regime, announced by the term "BAME" (Black, Asian, and Minority Ethnic), communities have competed against one another for funding. In this divisive context, some BEATS members narrated their exclusion from wider anti-racist organisation due to racialised constructions as a model minority. As Joy Muhammad said,

It's sometimes even difficult to classify yourself as BAME because you have other communities saying, "you don’t deserve to identify as BAME because you're not deprived enough.”

The BEATS network was seen a necessary response to similar marginalisation within antiracist networks in the CCIs, which, according to another participant, "were meant to be super, super inclusive, but weren't," and tended to overlook East and Southeast Asian experiences.

While the term "British East (and Southeast) Asian" has been in circulation at least since the early 2000s, in participants' narratives, a turning point in its "weaponisation" was sparked in 2012, when the Royal Shakespeare Company (RSC) staged a production of the Chinese play, The Orphan of Zhao, known as the "Chinese Hamlet" and set in China. By casting white actors in all the major roles, the RSC endorsed "Yellowface" practices. The only three East Asians cast were in minor roles, namely as two maids and a dog. In response, a group of actors led by Lucy Sheen, Paul Hyu, Daniel York Loh, Jennifer Lim, and others swiftly mobilised under the name of "British East Asian Artists" and organised a protest. It was a significant moment, highlighting the injustice of dehumanisation and erasure and a refusal to accept it, sparking several similar protests. Notably, it was a specifically a pan-Asian identity that was mobilised, with support from East and Southeast Asians globally, particularly Asian Americans, with whom a sense of community was already emerging. Singapore-born Lim, who had appeared in a production of Wild Swans in London the year before, described her first experience of being in a full pan-Asian cast, alongside actors of Asian American, Japanese, Indonesian, Chinese, Taiwanese, and Hong Kong heritage as a "very wonderful and empowering experience”:

I'd never worked with a full Asian cast before, it was my first one. I can't tell you, I've never felt this way before. We hung out so much and on the last 
day ... I was close to tears thinking I'm never going to see some of them again. We were like family. It's going to make me cry in a minute [laughs].

But it was such a seminal experience in my life.

The way in which Lim talks about this emergent pan-Asian community in a language of love - both intimate and familial - is significant, as expanded upon below. However, as with Asian American leaders in the US, of both past and present generations (Espiritu, 1992; Nakano, 2013), Lim sees the significance of pan-Asian organisation as lying in its capacity "as a strong political term" to garner greater "bargaining power." This raises the perennial question of how to create a politics of difference, which is discussed next.

\section{A Politics of Difference}

When discussing the mobilisation of a pan-Asian identity, Muhammad stated, "it's for us to collaborate and make a stand that 'we're not the same, but we are going through the same kind of shit right now and we're not going to take it anymore."' In doing so, she articulates the struggle, as Hall (1988: 28) describes, of "how to build those forms of solidarity and identification which make common struggle and resistance possible but without suppressing the real heterogeneity of interests and identities." In the US, research on Asian American mobilisation has conceptualised the relationship between ethnic and pan-ethnic organising in three ways: first, where pan-ethnic mobilisations supersede ethnic identifications; second, as situational where pan-ethnicities and single-ethnicities are mobilised according to context; and third, as interlocking, where they mutually affect each other (Nakano, 2013). These, it is argued, are necessary as leaders attempt to navigate differences within a diverse population. This also appears to apply to BEATS. As Sheen stated, "we're advocating for the wider society to see us in our diversity, in our uniqueness as well as our overall groupness, and not to omit us." The way in which this takes place is shaped by both specific conceptions of "Chineseness" circulating in the dominant discourse as well as the overall hegemony of Chineseness over other East and Southeast Asian identities in Britain.

\section{Contesting Chineseness}

As in my previous research among young people in the nightlife economy (Yeh 2014a, 2014b), a pan-Asian identity is embraced by BEATS members as an inclusive category to encompass complicated mixed heritages or cultural influences in response to narrow conceptions of Chineseness and the policing of its authenticity. Recalling the mobilisation in response to The Orphan of Zhao, Sheen, a transracial Hong Kong-born adoptee, recalled:

We all wanted it to be pan-Asian. Because up until that point it had been incredibly Chinese-centric and particularly Hong Kong Chinese-centric within the theatrical world.

Despite her place of birth and appearance, Sheen felt excluded, due to particular demands around ethnic authenticity: "I don't naturally speak Cantonese or Mandarin. Yes, I was born in Hong Kong, but I was raised here. So, in that narrow definition, I am not 'authentically' Chinese." Loh, of "mixed" Singapore Chinese and English heritage, recounted similar experiences of the policing of Chineseness among both "Chinese" and "white” people:

I’ve spent a lifetime of Chinese people saying to me, "Oh but you're not really Chinese.” I find that fundamentally offensive ... but the ethnic authenticity thing is also about white people maintaining their power... "that's how you'll have to prove yourself to me." 
For Mingyu Lin, a pan-Asian identity was also embraced as a means of side-stepping the violence of misrecognition and the exhausting work of explaining one's identity:

Every time I say "I’m Chinese,” they say, “Oh you're from China,” or they say, "Oh, but I thought you said you were from Singapore,” and I have to say "yes, the two can correlate."

Yet central to concerns over Chineseness - particularly in the context of the Hong Kong protests of 2019-2020, over Beijing's plans for an extradition bill, and its human rights record were versions propagated by the People's Republic of China. As Lim articulated:

If you're talking about nationality, you should be including the Tibetans, the Huis, and the Uyghurs, but they are not being included. And by dint of association with the state of China, suddenly its foisted on you to be responsible for what this state is perpetrating on a global level.

While these narratives testify to the embrace of a pan-Asian identity as a means of contesting the borders of "Chineseness," for Muhammad, it also makes space for a heritage across East and Southeast Asian borders:

I describe myself as a mixed Asian-Sussex girl. But if you want to break it down more, Malay-“Chindian.” If you want to break it down even more, Malay-Indonesian-Tamil-Hakka and raised with British and Malay culture but embracing the other two ethnicities.

The lack of public understanding of the complexity of "East and Southeast Asia" however has led her to use "JM Arrow" as a pen name instead:

If I was going to write a piece about being East Asian and my name is Joy Muhammad people aren't going to think “East Asian,” they're going to think, "Er, OK, is it someone pretending to be East Asian? Is it someone who's appropriating it?" It's easier to use a "Western" pen name - which means that ... I have to hide the very identity that I'm proud of.

Nonetheless, in her creative work, Muhammad, like other BEATS members, draws on her complicated positioning to explode simplistic identity categories. In Do My Eyes Look Small in This? (2020), Muhammad provides insight into the intersectional nature of her experiences as a "British female bisexual feminist of mixed Asian and religious heritage." ${ }^{5}$ The monologue is performed by Peyvand Sadeghian, an actor who describes herself in her Twitter profile as a "Cockney-Chinese-Persian mishmash.” While putting on her makeup and hijab, the young woman talks about her everyday experiences of racism as a mixed Chinese Muslim bisexual woman:

When the 9/11 attacks happened, I knew people of my religion were going to get the blame. Now with the Covid-19 crisis it's people of my race. I can only think, "Here I go again" ...

I remember the first time I wore a hijab. Someone went up to me and asked, "Excuse me, why are you wearing a headscarf? You're Chinese." ...

I've been kicked out of gay venues for looking too feminine and straight and just not white enough, because apparently us Asians are too geeky for

\footnotetext{
${ }^{5}$ See https://www.omnibus-clapham.org/oto-we-r-not-virus/.
} 
pretentious - sorry "cool” - venues. I was accused of being a DVD seller at one gay bar.

For these cultural workers, then, a pan-Asian identity creates a more expansive category than "Chineseness" that makes space for their unruly "Chinese" heritages while also allowing them to disassociate from the Chinese state. That questions of Chineseness are central to deliberations over pan-Asian identity signals its hegemony within the group, despite efforts made by members to craft an inclusive political community, as discussed next.

\section{The hegemony of Chineseness}

Due to colonial histories, "Chinese" and "British Chinese" have been hegemonic other "East and Southeast Asian identities" (Yeh, 2014, 2018). This is reflected in the problematic use of the term "British East Asian" in the arts to include - while also arguably rendering invisible - Southeast Asia (Yeh, 2018). ${ }^{6}$ The dominance of East Asian, and specifically Chinese and Japanese, interests and experiences in mobilisations of pan-Asian identities is well documented in the US (Nakano, 2013), where, as in the UK, it reflects the relative positions of power of East Asian by comparison to Southeast Asian groups. This hegemony is evident in BEATS in its very naming. When founding the network, a member of Southeast Asian heritage proposed the name S/EAN to stand for "Southeast /East Asian Network," but eventually the group settled on BEATS (British East Asians in Theatre and on Screen), capitalising on the growing currency of the term "British East Asian” in the stage industry. In conversation with this member, they said:

I'm someone who's always had to contend with being painted ... as just being Chinese because there's no way to interpret who I am anyway, so it's better than being called "Chinese.” It's not the same as being called Southeast Asian but I accept it as progress. But I know a lot of people who come from Southeast Asia probably feel a dissatisfaction.

This response is shaped by the common experience of the violence of misrecognition, whereby, due to the dominance of Chineseness in the British imagination, "anyone looking East Asian" is assumed to be "Chinese" (Barber, 2015). For this participant, "British East Asianness" provides an expanded category that lessens this violence, while sustaining another - the East over Southeast Asian hierarchy. ${ }^{7}$

Since its launch in 2018, BEATS' film screenings have included works by a range of East and Southeast Asian filmmakers, and the collective has supported its members' plays - Loh's Forgotten (2018), about Chinese labourers in the First World War, and Tuyen Do's Summer Rolls (2019), dubbed the first British Vietnamese play. Its advocacy work tackles issues that either affect East and Southeast Asians universally, such as the use of "Yellowface" in the English National Opera's 2020 production of Madame Butterfly, or is framed in that manner. ${ }^{8}$ While

\footnotetext{
${ }^{6}$ For example, David Tse states that "East Asia” is defined as "the area east of Pakistan and west of the Americas," although arguably this is due to practical reasons of economy of expression, rather than any ideological intention to exclude (Arts Council of England, East Midlands Arts Board, Theatrical Management Association, and Nottingham Playhouse, 2001: 57).

${ }^{7}$ Over the past few years - and especially among the newer formations of pan-Asian political community emerging in the Covid-19 era, the term British East and Southeast Asian is increasingly taking precedence. Indeed, BEATS' own consideration of a name change to BESEAn (British East and Southeast Asian Network) to promote greater emphasis on Southeast Asian experience was stalled due to another collective laying claim to this name.

${ }^{8}$ Its first campaign, for example, was a protest against the children's television channel CBBC's plans to create a children's sitcom Living With The Lams about a Chinese family running a restaurant in Manchester, with almost all of the episodes authored by "non-East Asian” (rather than non-Chinese)
} 
much of its work reflects a greater engagement with East- over Southeast Asian-related cultural productions, this partially arises from its responsiveness to instances of injustice in national cultural institutions, which reproduces local and global hierarchies in the economy of East and Southeast Asians and their diasporas.

Despite efforts to recruit new members to redress the imbalance, the continued ethnic Chinese dominance of the group is a source of frustration for members. As one interviewee put it:

The thing that worries me about the pan-Asian thing is actually those people especially from the more marginal countries, Laos, Cambodia, the Philippines, come way, way down and then that perpetuates the Chinese dominance, and then, I'm like “Ah, we're even unequal in our own little bubble of things."

The work of BEATS' members outside the collective tackles pan-Asian representation more successfully. Programmes such as Moongate Productions' "WeRNotVirus" (2020), a festival of works responding to COVID-19-related anti-Asian racial violence, for example, brought together cultural workers of Chinese, Vietnamese, Indonesian, Japanese, and Korean (and including mixed) heritages. Members also play a key role in supporting new generations of East and Southeast Asian artists. For example, Sheen and Loh have directed monologues for the "British East \& South East Asian (BESEA) Graduate Digital Showcase" (2020) produced by Adrian Tang, which included graduates of Chinese, Japanese, Vietnamese, Thai, Malay, Filipino, Korean, Singaporean, and Uyghur-Uzbek descent.

Literatures on anti-racist organising often highlight the challenges of crafting a politics of difference across "internal frontlines" of ethnicity (Hall, 2000: 17). Here, while the hegemony of "Chineseness" within BEATS continues, members actively seek to challenge it, though more research is still required on the extent to which workers of other East and Southeast Asian backgrounds feel represented by the collective. What is clear however is that more significant fault-lines within this stage and screen community lie elsewhere - and that is in divisions over political orientation, as discussed next.

\section{Between Radical and Integrationist Politics}

In this section, I argue that an overarching tension within the British East and Southeast Asian screen and stage community lies in a division between more radical and integrationist politics. These are marked by different political strategies, with BEATS members constructing themselves in opposition to those whom they perceive to be seeking a collaborative, model minority relationship with establishment culture to achieve what are viewed as limited, if not assimilatory, forms of representation. This tension, I suggest, highlights what I identify as a disavowal of racism against the Chinese (and at times, East and Southeast Asians more widely), as a consequence of racialising constructions as a model minority. Its internalisation, I argue, along with a broader incorporation of epistemologies of whiteness, works to defuse radical political agency. This

writers. Subsequent campaigns include objections to the flying in on taxpayers' money of Asian American actors to the British stage in Arts Council-funded Hampstead Theatre's King of Hell's Palace (2019) (set in China) and Theatre Royal Bath's Wild Goose Dreams (2019) (set in South Korea), which have contested the erasure of opportunities for specifically British East and Southeast Asians regardless of specific ethnicity. (For BEATS, the "Britishness" articulated here is emphatically not determined by citizenship rights, but choice of place to live and work, although its use is vociferously contested those who are unaware of this.) 
signals the importance of a politics of love and care as a means of sustaining more radical attempts to achieve racial justice.

According to BEATS members, the building of pan-Asian solidarity was critical during the Orphan of Zhao protests of 2012, due to the disappointing response from British-based ethnic Chinese. As Lim recounted, "if you only canvas for support from the [British] Chinese community . . . you'll get fuck all.” British East and Southeast Asian identity is therefore constructed as emphatically political in direct contrast to both stereotypes and experiences of British Chinese peers as apolitical. This is evident in participants' continual emphasis on the need to "make a stand," and highlighted in Loh's reclamation on his Twitter profile of his labelling as a "militant" and an "\#Angryethnic," within and beyond East and Southeast Asian communities, for his role in speaking out. Significantly, the pan-Asian identification enables participants to challenge racialised constructions of the Chinese as a quiet, submissive model minority: in Loh's words, "East Asians are known in the industry as being quite small in number but feisty as fuck [laughs]. I think everyone knows you don't mess with British East Asians.” While constructed in opposition to "Chineseness," this pan-Asian identity is not, however, "anti-Chinese" so much as defined in opposition to apolitical, assimilatory, or culturalist constructions - and politically regressive model minority expressions - of both British Chineseness and British East and Southeast Asianness, as discussed next.

\section{"Playing the model minority, the yellow face"}

As with the mobilisation of the category of Asian American in the US, the claiming of a panAsian identity has emerged as a rejection of the racist, colonialist term "Oriental," which, as BEATS member Lim articulated, "carries with it so many connotations, of being mythical, of being not quite real, and exotic." BEATS members are similarly critical of the embrace by their peers of the term "Yellow." Despite the fact that, as Sheen argues, the label was "made up mostly to belittle and denigrate a whole race of people ... [and] constructed to make [us] feel less than human,” it was institutionalised in the British cultural landscape when the Yellow Earth Theatre was set up in 1993.

Representations of East and Southeast Asians on the British stage and screen are rare (Rogers, 2020), and it is Orientalising practices that limit those representations to a handful of tropes, of what Loh calls "little Yellow people": women as submissive and sexualised "Madame Butterflies" and men as tyrants or triad members, or emasculated and weak. Contestations of Othering forms of representation, however, are problematised because, as Sheen said, there are many "who are willing to play the model minority, the yellow face" or to "play foreigners." That, as Loh points out, "there's quite an easy living to be made doing it" underlines how the livelihoods of racialised cultural workers hinge on a self-Othering as ethnicity becomes commodified (hooks, 1992; Saha, 2013), making it a common rationale for taking up such work, and resulting in an unwillingness to challenge it.

Another BEATS member described actors rehearsing for a play:

They bring up things like, "Oh, it's very Orientalist to walk across the stage [like that], we don't like it, we should do something about it.” But then the director comes in and everyone's suddenly quiet. In front of me, they're huge activists. In front of white directors, they will throw British East Asians under the bus.

Being on the frontline, members of BEATS recognise the very real fear of the repercussions of speaking out - that of being blacklisted - but this can aggravate rather than assuage frustrations over a lack of mobilisation. As Loh, one of the most outspoken critics said, "I've really risked my 
whole career at times. It was quite intimidating at times and people just take that, and just don't bother." What is deemed particularly pernicious is that objections around misrepresentation can be directed at other East and Southeast Asians but not the white establishment. Loh recounts recent criticism within the community of representations of Singapore by Anchuli King, a 24year-old Thai Australian New Yorker, who wrote White Pearl (2019), staged in London:

You'll call out Anchuli but you wouldn't say boo to Lucy Kirkwood, you wouldn’t say boo to Michael Boyd. . . . You would crawl over broken glass to act in Lucy Kirkwood's crap representations of China with those crap Chinese accents. You'd absolutely kill to be in that ...

As he commented, "All that angst and anger and wrath that they should reserve for [the white establishment]. They actually give to you." With respect to the Asian American experience, Matsuda (2010: 561), has written about "displaced anger" as "a victim's mentality; the tragic symptom of a community so devoid of self-respect that it brings its anger home." In this context, "playing the model minority, the yellow face" is not limited to an actor's life but can be seen as a metaphor for wider political orientation in the world. That is, maintaining the status quo not only by not speaking out, but by overvaluing, embracing, and even protecting whiteness, even as it compromises one's own humanity.

However, we need to understand how this occurs not simply in the context of a very real need for artistic and economic survival or the abject status of East and Southeast Asians in Britain but also in the context of our post-racial condition. Goldberg (2015) has theorised post-racial discourses the denial of racism - as precisely one of the powerful ways in which racism reproduces itself. This is evident in narratives reported by BEATS members. Lim describes participants in one theatre workshop asking,

Why do we want to talk about issues? Why don't we do something universal? Why do we have to talk about identity? Why can’t we just ... play universal parts?

In pitching "identity issues" - in other words racial/ethnic identity against what constitutes the "universal" - participants reproduce discourses in which whiteness is understood as an unmarked, neutral position - the universal - rather than a specific and actively sustained position of power (Lipsitz, 1998). As a result, they believe they can play the "universal," that these parts and stories are open to them (if only they stop talking about their identity). In this way, they further reproduce colour blind discourses that disavow racism while simultaneously negating the possibility that "Chinese" or "Asian" stories can be "universal."

Even when there is recognition of being subject to and delimited by racialization, there remains a desire to participate in that unmarked whiteness. Loh reported an actor as saying, "I think it would be great not to be defined by our race, it would be great to do a Sarah Kane play.” In Lim's analysis,

It's almost as if you've got an unconscious bias against your own narratives, and I find it quite disturbing. As if we've been indoctrinated to such an extent that we feel our own stories are not worth telling. It's better to blend in with the majority race in this country, so we should tell their story, and be part of them and be them, be white.

Lim here speaks precisely of an assimilationist desire, a fantasy of attaining whiteness, which stems from an internalisation of whiteness as an epistemological standpoint in which East and Southeast Asian lives and stories have no worth or value. While such internalised racism affects all racialised minorities, the proximity of specifically East (and at times Southeast) Asianness to whiteness - where Asians, as a model minority, have been constructed in different 
contexts, from apartheid South Africa to the contemporary US, “as honorary whites” (Tuan, 1998) - creates a particular promise of achieving the privileges of whiteness, which binds us to its racial logics in a specific way. As Matsuda (2010: 559) writes, "The role of the racial middle is a critical one. It can reinforce white supremacy if the middle deludes itself into thinking it can be just like white if it tries hard enough.” The post-racial deepens this fantasy. In terms of actors, as Loh suggests, "they just expect to be cast as Nina in The Seagull," despite the reality that they find it hard even to get to play East and Southeast Asian roles, as the RSC production of The Orphan of Zhao suggests. But, as Lim questions, "why would they want to do something Russian? Why don't they want to play themselves?”

In a separate discussion, another BEATS member, in recounting coming to political consciousness, highlights the different routes and the stages of the journey among the collective, rooted in historically specific and localised experiences of migration and racism:

I didn't grow up in London - we came in the 1980s when I was about four or five. We were in a boat in the South China Sea, and we finally got picked up by a British boat, which meant we were diverted to Hong Kong. Maggie Thatcher wouldn't let us leave the boat because she didn't want any Vietnamese in the country, so we were actually left on the boat for ages until she finally relented and we were processed at [Hong Kong] and we came to the UK. The rule was, picked up by a British boat, come to UK, get picked up by a French boat, go to France, picked up by an American boat, go to America. I grew up in a shit town in the Midlands, which is a really, really racist place ... really, really poor, and a really hard place to grow up. So, I grew up my entire life wanting to be white.

This narrative of a childhood experience as a refugee captures not only neglect but hostile rejection by both states and, then, in everyday life, by the people of those states, through which this participant makes sense of a desire for whiteness. These experiences shape their political stance now, as the above interviewee (who wished to remain anonymous) would express: "It's probably one of the reasons why I think BEATS should be so compassionate to everyone. Not so long ago, I was that person with all that internalised whitewashing and racism towards myself." In speaking of compassion, this BEATS member points to an orientation of care, which, as a practice and discourse, has been far less visible within East and Southeast Asian than in other communities until recently. Loh, for example, speaks of "certain East Asians who are very comfortable with being the only one in the room. They like that, they want to preserve that hallowed status.” Rejecting the logic of tokenistic neoliberal inclusion embraced by others, with its emphasis on individual success, BEATS members' politics is underlined by a sense of what Emejulu and Bassel (2018: 114) call "care as praxis," a radical act that requires the development of a political imagination that takes seriously the lived experiences of both close and distant others. For Loh, this must be anti-imperialist and global: "Why don't British East Asians care about the Hong Kong protests? Why don't we care about each other?” They contest the internalized racism that overvalues whiteness and in doing so erodes the collective struggle for racial justice, and instead present a radical politics that encompasses both affirmation and refusal.

\section{A politics of affirmation and refusal}

There is a long history of the mobilisation of the concept of love (and self-love, or care) (Lorde 1988) in Black, feminist, queer, and critical race writing, in which it is seen as means of constructing political communities (Nash, 2013), as a source of survival and a precondition for 
love across boundaries (Anzaldúa, 2009 [1988]). For hooks (1992), “loving blackness” can be theorised as a revolutionary act of psychological and political decolonisation that breaks with white supremacist thinking. While recently concepts of care have been mobilised by government and policymakers in the deepening of neoliberal objectives, and in the UK, of dismantling the welfare state (Ward, 2015), there has also been a resurgence of an ethics of care emerging in racially marginalised communities that revives its more revolutionary roots (Emejulu and Bassel, 2018). What I hear from BEATS' members are narratives and practices that contest the selfOthering and devaluation attributed to wider community members, and which can be described as expressions of "loving Asianness" via a revaluing of the lives, humanity and worth of themselves and others. This act of love acts as a catalyst to and is a necessary precursor to a radical politics of affirmation.

This can emerge as a refusal to defer to powerful gatekeepers, as in the case of a young director who recounted the words of a white director of a Chinese-themed play: "Perhaps in the future, in a more mature world, you could direct it," which illustrates a continual deferral of the representation of racially marginalised communities to a future time (Naidoo, 2013). (The young director's response: "I'm not going to go 'Oh thank, you.' No, no, no, no, no - I can do it now..) It can also find expression as a necessary claim of wider collective worth. As Loh has said: "We have to believe our stories and our lives are worth caring about." Referring to other community members working on a serious Chinese play, who seemed to joke around on stage rather than engaging deeply with the play, he says:

They don't realise that it's a massive story, about people's lives, people whose stories don't get told. There's a lot of people in China, a lot of brave people, a lot of people who disappear. It's important. It's important you do that, and you do that right. I don't understand how you can just piss away that humanity. ... .

I want to do more East Asian stories, more East Asian roles. . . . I’ve been the only one in a white cast, and you think "yeah, I'm living the dream" in many ways, but I don't feel comfortable about it. I've only felt comfortable doing East Asian stories, good ones ... the good ones have been nothing I've felt prouder of, and nothing I've felt more thrilled by.

Speaking of the "thrill" of Asian stories, Loh raises the issue of pleasure here, which is significant. It helps emphasise political resistance, not only as reactive - voicing the dispossessed - but as joyful and life-giving, as a form of affirmation that is generative and that can spur further collective political action. Thus, while a significant aspect of BEATS' work lies in advocacy, which are conventionally political strategies, as another BEATS member says, "there are other ways to do advocacy. That could be about sharing work, bringing people up in other ways, showcasing work." BEATS thus also works to change the economy of East and Southeast Asian representation so that there is "plenitude" and "abundance," by acting as "gate openers not keepers" by opening up channels to institutions as well as nurturing talent.

Yet, as theorists have pointed out, political love can also be exclusionary and caring for others can be an act of refusal (Emejulu and Bassel, 2018). The specific modes of "loving Asianness" in the British East and Southeast Asian community are highly contentious. While BEATS members' views are far from homogeneous, they share a belief in the necessity of "speaking truth to power" and of contesting both structural inequalities and the politically regressive neoliberal "model minority" politics that they identify in the anti-racism of others. Yet the radical nature of their politics can be alienating. In two recent works, Invisible Harmony (2020, 
with Enxi Chang), and No Time for Tears (2020), ${ }^{9}$ Loh provides an impassioned redefinition of Asians as political agents. Yet the works also excoriate fellow Asians who "don't raise the bar ... [and] just suck it up," whether on stage or screen ("You take the profit workin' out that yello butt / You so exotic, to the white patriarch you butter up"), or beyond ("Don't care about the climate or the world or Brexit / The rubber bullets and the tear gas on the streets from your mind you edit”) (Loh and Chang 2020). They are also critical of neoliberal constructions of Asianness in which communities build Asian worth through - and as - commodities: noodles, bubble tea, and Asian bodies ('You postin' up your dan dan on subtle Asian traits / Gettin' shiny headshots an' pumpin' them weights / You believe in your hype so you raisin' up a boba”) (Loh and Chang 2020). While elsewhere,

The girl and the boy in a world that's cleft

Their fragile bodies so easily shattered

And peppered with spray made in the West

And pierced with bullets of rubber that crack and spatter. (Loh and Chang 2020: n.p.).

In No Time for Tears (2020: n.p.), Loh explicitly denounces model-minority politics not only for its effects on Asians but also as used against Black people.

I've been congratulated in the past on my "community"'s [sic] quietness and politeness. The fact we're not pesky trouble-makers like those other people of colour...

That we should be

Proud

To be so untroublesome

But I'm not proud of that

In fact I'm ashamed ...

To remain in a tract of docile employ

Yet weaponised enacted when you chose to deploy

Us to beat down on Black people you casually destroy

.

So fuck your model minority card. I never wanted it any way

It didn’t get me in your club.

This is an analysis that challenges the divisive ethnicised regime by connecting anti-Asian racism to other racisms ("While an antisemitic conspiracy brews / And Muslim migrant blame ensues / And Africans are homeless in the province of Guangzhou), and in opposition to a modelminority politics in which Asians only care about racism against themselves.

This, I argue, demonstrates how British East and Southeast Asian mobilisation is an identity-based politics that is not necessarily divisive but can be an expansive force that opens up possibilities of solidarity across racial and other differences, but one that is simultaneously, in Emejulu and Bassel's (2018: 115) words, "an act of refusal.” As with the activists they interview, for BEATS members, caring for Others includes speaking out and acting against neoliberal and racist, as well as sexist, homophobic, ableist, and transphobic, regimes - especially (but not exclusively) when perpetuated within British East and Southeast Asian circles. I therefore suggest that in this instance of crafting political community then, the major faultlines lie not along ethnic - nor even racial - lines, but are rather constituted through particular political projects and

\footnotetext{
${ }^{9}$ Both texts were made available to me as a panel speaker at events where the works were performed or shown, 'Invisible Harmony' at the Southbank Centre, London, 4 February 2020 and 'WeRNotVirus', Omnibus Theatre, London, 14 June 2020. They are cited with permission from the author.
} 
boundaries of otherness. In adopting a more radical path, BEATS separates itself from more integrationist forms of politics that has arguably dominated the pan-Asian screen and stage community, if not Britain's Chinese communities thus far.

\section{Conclusion}

In this article, I have argued that "British East and Southeast Asian" mobilisation in the CCIs is significant as a new form of expanded "pan-Asian" political community, which testifies to the changing social and political dynamics of the "Chinese in Britain." Focusing on the political dimensions of constructions of "British Chinese community" within and beyond the borders of "Chineseness" is necessary to ensure that academia is not complicit in reproducing racialised stereotypes of an apolitical model minority. As a partner-in-struggle, I make the case for repositioning "Chinese" and "East and Southeast Asian" women in particular, who make up the majority of BEATS' members, but others too, as political actors and agents of change. In so doing, I contribute to the documentation of histories of East and Southeast Asian anti-racist activism that so far remain scant in the literature. As this article has shown, the weaponisation of a pan-Asian identity by BEATS marks the growth of nascent radical political energies that seek to break with integrationist politics that are viewed as defending the status quo and acquiescing to self-othering in exchange for inclusion. Instead, BEATS directly challenges the legitimacy of key cultural institutions, their structures and their practices, which is significant in a context where understandings of racism are individualised and reduced to interpersonal antagonisms, rather than seen as systemic and structural.

At the same time, this article has shown how the divisions and difficulties in mobilising demonstrate how entrenched anti-Chinese and anti-Asian racism is. The lack of mobilisation occurs in a context where Chineseness and Asianness is abject - still ridiculed and denigrated as a normalised part of public life - and it is sustained by colour blind promises of equal opportunity and discourses of a post-racial meritocracy. I argue that the disavowal of racism against us is precisely one of the powerful ways in which we experience racism, in the way it works to delegitimise and contain our political agency. In a post-racial context, the denial of racism affects all racially minoritised groups. Yet in the case of the Chinese and at times East and Southeast Asians more widely, the disavowal of racism is specifically shaped by racialisation as a model minority with proximity to whiteness. Amid the allure of being included, strategies such as the downplaying of difference, endeavours to participate in "whiteness," and the valuing and protecting of the white cultural establishment are perceived to be employed within more integrationist politics. Obscuring institutional racial workings, they are underpinned by an ambivalent and simultaneous recognition and disavowal of racism, in the belief that playing the model minority provides a path to empowerment.

In this context, I have proposed that, among BEATS' members, "British East and Southeast Asian" marks a distinct political imaginary defined by a more radical approach that contests model minority integrationist approaches, in collective efforts to effect political and social change. As I have shown, a range of strategies are deployed, including challenging the legitimacy of key cultural institutions, tackling structural processes, and working against the divisive ethnicised regime, as well as engaging in a wider politics of representation. Yet this article contributes to the literatures particularly in highlighting the central role of the politics of love and care in this women-led mobilisation. This includes, in the CCIs, insisting on the value of Asian lives by advocating for Asian-led and Asian-performed stories and roles, creating autonomous "pan-Asian" spaces of production and community building, and nurturing and uplifting the work of others to create plenitude and abundance in the economy of representation. In a context of a continued abjection that is disavowed, I have argued that "loving Asianness" as a radical revaluing of Asian lives, humanity and worth becomes life-giving, a necessary source of 
building capacity to resist, of galvanising political movement and as a shared basis for developing a politics of affirmation and refusal of all forms of oppression.

Significantly, this demonstrates that the mobilisation of "British East and Southeast Asian" as a form of identity-based politics can be an expansive force that opens up, rather than forestalls, solidarities across racial, gendered, sexual and ableist and other forms of oppression. While this article has focused on BEATS, there has been a surge of political mobilising among Britain's East and Southeast Asian communities in the Covid-19 era as a response to the anti-Asian racial violence it has sparked. This demonstrates further both the potential and challenges that a politics of love and care might have for building broader solidarities within and beyond British Chinese communities. Future research must now follow the extent to which these groups are able to craft "East and Southeast Asian" identities that build resistance across different forms of oppression and the role of love and care in thus reshaping the political horizons of these communities more widely.

\section{References}

Alexander, Claire (2002), “Beyond Black: Re-thinking the Colour/Culture Divide,” Ethnic and Racial Studies 25 (4): 552-571.

Anzaldúa, Gloria (2009 [1988]), "Bridge, Drawbridge, Sandbar, or Island: Lesbians-of Color Hacienda Alianzas,” in AnaLouise Keating, ed., The Gloria Anzaldúa Reader, 140-156, Durham, NC: Duke University Press.

Arts Council of England, East Midlands Arts Board, Theatrical Management Association, and Nottingham Playhouse (2001), "Eclipse Report: Developing Strategies to Combat Racism in Theatre," available at: https://www.artscouncil.org.uk/sites/default/files/downloadfile/Eclipse_report_2011.pdf (accessed 10.06.2021).

Barber, Tamsin (2015), Oriental Identities in Super-Diverse Britain: Young Vietnamese in London, Basingstoke: Palgrave Macmillan.

Bassel, Leah and Emejulu, Akugwo (2017), Minority Women and Austerity: Survival and Resistance in France and Britain, Bristol: Policy Press.

Benton, Gregor, and Edmund Terence Gomez (2008), The Chinese in Britain, 1800-Present: Economy, Transnationalism, Identity, Basingstoke: Palgrave Macmillan.

Emejulu, Akwugo, and Leah Bassel (2018), “Austerity and the Politics of Becoming,” JCMS: Journal of Common Market Studies 56: 109-119.

Espiritu, Yen Le (1992), Asian American Panethnicity: Bridging Institutions and Identities, Philadelphia, PA: Temple University Press.

Goldberg, David Theo (2015). Are We All Postracial Yet?, London: John Wiley \& Sons.

Hall, Stuart (1988), “New Ethnicities,” in Black Film, British Cinema, ICA Documents 7, London: ICA.

Hall, Stuart (2000), "Frontlines/Backyards," in Kwesi Owusu, ed., Black British Culture and Society, 127-130, London: Routledge.

Harvie, Jen (2013), Fair Play: Art, Performance and Neoliberalism, Basingstoke: Palgrave Macmillan. 
HESA (n.d.), “Top Ten EU and Non-EU Countries of Domicile (Excluding the UK) in 2019/20 for HE Student Enrolments 2015/16 and 2019/20," available at: https://www.hesa.ac.uk/data-and-analysis/sb258/figure-11 (accessed 22.06.2021).

hooks, bell (1992), Black Looks: Race and Representation, Boston, MA: Southend Press.

Huq, Rupa (1996), “Asian Kool? Bhangra and Beyond,” in Sanjay Sharma, John Hutnyk, and Ashwani Sharma, eds., Disorienting Rhythms: The Politics of the New Asian Dance Music, 61-80, London: Zed Books.

Kim, Helen (2017), “'We're Just Like Everyone Else!': Rethinking the Cultural Politics of the London Asian Urban Music Scene,” European Journal of Cultural Studies 20 (2): 125140.

Knowles, Caroline, and Roger Burrows (2017), "Reimagining Chinese London,” in Suzanne Hall and Ricky Burdett, eds., The SAGE Handbook of the 21st Century City: 87-103, London: SAGE.

Knox, Simone (2019), "Representations of British Chinese Identities and British Television Drama: Mapping the Field,” Journal of British Cinema and Television 16 (2): 125-145.

Kondo, Dorinne (2014), About Face: Performing Race in Fashion and Theater, New York: Routledge.

Lipsitz, George (1998), The Possessive Investment in Whiteness: How White People Profit from Identity Politics, Philadelphia, PA: Temple University Press.

Littler, Jo (2018), Against Meritocracy: Culture, Power and Myths of Mobility, Abingdon: Taylor \& Francis.

Lorde, Audre (1988), Lorde: A Burst of Light: Essays, Ithaca, NY: Firebrand Books.

Loh, Daniel York (2020), No Time for Tears, unpublished and unpaginated manuscript.

Loh, Daniel York and Enxi Chang (2020), Invisible Harmony, unpublished and unpaginated manuscript.

Matsuda, Mari J. (2010), “We Will Not Be Used: Are Asian Americans the Racial Bourgeoisie?,” in Jean S. Wu and Thomas C. Chen, eds., Asian American Studies Now: A Critical Reader, 558-564, New Brunswick, NJ: Rutgers University Press.

Mondon, Aurelien, and Aaron Winter (2020), Reactionary Democracy: How Racism and the Populist Far Right Became Mainstream, London: Verso Books.

Naidoo, Roshi (2013), “Diversity after Diversity,” Third Text, available at: http://www.thirdtext.org/diversity-after-diversity (accessed 10.06.2021).

Nakano, Dana Y. (2013), “An Interlocking Panethnicity: The Negotiation of Multiple Identities among Asian American Social Movement Leaders,” Sociological Perspectives 56 (4): 569-595.

Nash, Jennifer C. (2013), "Practicing Love: Black Feminism, Love-Politics, and Postintersectionality,” Meridians: Feminism, Race, Transnationalism 11 (2): 1-24.

Parker, David (2003), “Is There a British Chinese Public Sphere?,” in Gary D. Rawnsley and Ming-Yeh T. Rawnsley, eds., Political Communications in Greater China: The Construction and Reflection of Identity, 239-60, London: RoutledgeCurzon.

Parker, David, and Song, Miri (2006a), "Ethnicity, Social Capital and the Internet: British Chinese Websites,” Ethnicities 6 (2): 178-202.

- - - (2006b), "New Ethnicities Online: Reflexive Racialisation and the Internet," The Sociological Review 54 (3): 575-594. 
- - - (2007), "Inclusion, Participation and the Emergence of British Chinese Websites," Journal of Ethnic and Migration Studies 33 (7): 1043-1061, DOI: 10.1080/13691830701541564.

- _ - (2009), "New Ethnicities and the Internet: Belonging and the Negotiation of Difference in Multicultural Britain,” Cultural Studies 23 (4): 583-604.

Parmar, Pratibha (1982), “Gender, Race and Class: Asian Women in Resistance,” in Centre for Contemporary Cultural Studies (CCCS), ed., The Empire Strikes Back: Race and Racism in 70s Britain, 235-74, London: Routledge.

Rogers, Amanda (2014), Performing Asian Transnationalisms: Theatre, Identity, and the Geographies of Performance, London: Routledge.

Rogers, Jami (2020), Diversity in Broadcast Peak Scripted Television, 2018: A Report Commissioned by Equity's Race Equality Committee, London: Equity.

Saha, Anamik (2013), “'Curry Tales': The Production of Race and Ethnicity in the Cultural Industries,” Ethnicities 13 (6): 818-837.

Thorpe, Ashley (2018), “The Arts Britain Utterly Ignored: Or, Arts Council Revenue Funding and State Intervention in British East Asian Theatre in the Late 1990s and Early 2000s," in Ashley Thorpe and Diana Yeh, eds., Contesting British Chinese Culture, 195-222, Basingstoke: Palgrave Macmillan.

Tuan, Mia (1998), Forever Foreigners or Honorary Whites? The Asian Ethnic Experience Today, New Brunswick, NJ: Rutgers University Press.

Vrikki, Photini. and Malik, Sarita. (2019), "Voicing Lived-Experience and Anti-racism:

Podcasting as a Space at the Margins for Subaltern Counterpublics," Popular Communication 17 (4): 273-287, DOI: 10.1080/15405702.2019.1622116.

Ward, Lizzie. (2015), “Caring for Ourselves? Self-Care and Neoliberalism,” in Marian Barnes, Tula Brannelly, Lizzie Ward, Nicki Ward, eds., Ethics of Care: Critical Advances in International Perspective, 45-56, Policy Press, 2015.

Yeh, Diana (2014a), “Contesting the 'Model Minority': Racialization, Youth Culture and 'British Chinese'/’Oriental’ nights,” Ethnic and Racial Studies 37 (7): 1197-1210.

_ _ — (2014b), "New Youth Mobilities: Transnational Migrations, Racialization and Global Popular Culture," in Veale, Angela and Dona, Giorgia, eds. Child and Youth Migration, 91-115, London: Palgrave Macmillan.

_ _ _ (2018), "The Cultural Politics of In/visibility: Contesting 'British Chineseness' in the Arts,” in Ashley Thorpe and Diana Yeh, eds., Contesting British Chinese Culture, 3159, Basingstoke: Palgrave Macmillan. 